\title{
La Ciudad como imposible y farsa. Una lectura crítica de Mario Levrero
}

\author{
¿ Blas Gabriel Rivadeneira / Universidad Nacional de Tucumán - conicet \\ lev_1984@yahoo.com.ar
}

\section{Resumen}

Proponemos una lectura crítica de la novela $L a$ Ciudad (1970) del escritor uruguayo Mario Levrero. La novela integra junto a El Lugar (1982) y Paris (1979) la denominada Trilogía Involuntaria del autor. La trilogía es involuntaria porque su conformación no parte de un plan previo ni de una continuidad argumental sino que es a posteriori de la publicación por separado cuando Levrero advierte una relación temática: la Ciudad. En este trabajo nos planteamos dar cuenta de las distintas operaciones escriturarias mediante las cuales se manifiesta en la obra la tensión entre la espacialidad urbana y la búsqueda de una territorialidad individual. La disputa entre cartografías ya trazadas y la necesidad de romper con la alienación personal es el eje sobre el cual se construye el viaje del protagonista, al tiempo que se desmonta uno de los pilares de la modernidad: la ciudad como ordenadora del imaginario.

Palabras clave: literatura latinoamericana $\cdot$ Mario Levrero $\cdot$ Trilogía Involuntaria $\cdot$ ciudad $\cdot$ territorialidad

\section{Abstract}

We propose a critical reading of Uruguayan writer Mario Levrero's novel La Ciudad (1970). Together with El Lugar (1982) and Paris (1979), the novel integrates the author's so-called Involuntary Trilogy. The trilogy is involuntary because its conformation does not come neither from a previous plan nor a plot continuity. It is after the separate publication of the novels when Levrero notices a thematic relationship among them: the City. In this work we set out to account for the different writing operations through which the tension between the urban spatiality and the search of an individual territoriality is expressed in the novel. The dispute between traced-out cartographies and the need to break personal alienation is the axis around which the protagonist's journey is constructed, while one of Modernity's foundations is dismissed as such: the city as a regulator of the imaginary.

Key words: Latin American Literature $\cdot$ Mario Levrero - Involuntary Trilogy $\cdot$ City $\cdot$ Territoriality 